\title{
IJTARP
}

\section{"Don't Say Anything You Can't Diagram." The Creative Brainstorming System of Eric Berne}

\author{
(C) 2019 Stephen B Karpman, MD
}

\begin{abstract}
This is a paper about the invention of ideas - and the protection of those ideas, including examples of Berne's original five rules of invention, and how they were successfully utilised by his followers, and the international organisation he set up to protect these ideas.
\end{abstract}

\section{Eric Berne In His Time}

The story begins in the 1960s during a time of social change in America. In those times a rebellious new freedom emerged to challenge any and all 'establishment' ideas in the arts, politics, music, science and social structures. The rebel heroes of the youth were the musicians, not the military. The bumper stickers on VW Bug autos read 'Question Authority'. The change proliferated among post-war baby boomers and hippies who refused to dress and act in the establishment way and were advising each other 'Don't trust anyone over 30'.

In those revolutionary social times of the 1960s the 'new' that was needed then was a way of explaining what people do with each other and why. People had a new interest in relationships in those times and Berne was the man to provide it. His Games People Play jumped to popularity in those years with over 100 consecutive weeks at the top of the New York Times national bestseller list (Berne, 1964a). Also, what was welcomed at the time was his PAC ego state model from that book that separated the authoritative Parent from the inquiring Adult - clarifying the difference between the two for that bumper sticker that read 'Question Authority'.

We can ask, did the times create Eric Berne or did Eric Berne create the times? Was his runaway bestseller Games People Play a participant or a follower of history? Berne and TA fit in well with the positive growth models of the day. He included a philosophy that believed that people were born OK - and others were OK too. Bad scripting could change that - but it was treatable with TA.

\section{Psychoanalysis - Time and Expense}

One such target for change inevitably were the psychoanalysts (and most of whom were over 30 ). This was the authoritative dominant theory of psychotherapy of the day, that required one-on-one individual therapy too many times a week over an expensive number of years. And the training was lengthy, controlled and expensive - not a peoples' psychotherapy. Berne once advocated for the "one session cure" that would save money and time. Eric Berne was a psychiatrist who briefly trained the psychoanalytic way but soon revolted and dropped out, later explaining "I could've spent the rest of my life disproving psychoanalysis but I decided to invent TA instead."

\section{The New Therapy Structures}

The first challenge to psychotherapy was to the structure, the one-on-one 50-minute therapy session, an elitist consulting room mandate that was quietly conducted behind closed doors between private and privileged individuals. This could now be replaced by the more socially popular, open, fun and less expensive group therapy. Berne shifted the focus of TA to group therapy so that transactions could be observed and recorded and discussed later with the trainees there in the outer observers' circle.

Couples' therapy became popular too as it would now spread the blame in an egalitarian way between both partners in a transactional dynamic rather than isolating just one person, with them realising that 'It takes two to play a game'.

Individual psychodynamic therapy for the troubled child too would be replaced by family therapy with the time's focus on the culture surrounding the individual child - the family who created that identified patient.

The private consulting room could now be moved to classrooms, rehabilitation centres, organisations and businesses for expertise in conflict resolution there. These paid well as a lucrative alternative for the 
individual therapist who could figure out how to make glossy brochures and bring psychological insights to the boardroom

The socially-involved post-war 'baby boomers' took to the structure of popular intensive weekend marathons and large educational seminars with rooms full of people, ideal for finding new contacts for friendships and sex. That generation of optimistic experimenters were following their mission to 'change the world' within their self-appointed 'Age of Aquarius.' They would try almost any experimental approach, including aromatherapy; primal scream therapy; mysticism, astrology and cults; Tarot card readings; past life regressions; tree hugging on drugs; and nude body 'touchy-feely' therapy in hot tubs. The San Francisco Bay Area was a hotbed for all those choices. Some therapists fought with each other to establish dominance and market share, polarizing their subjective versus objective belief systems and their opposite personalities, fighting it out as represented in a four-square Bias Box (Karpman, 1975a).

\section{Professional Resistance.}

Establishment psychiatry of course resisted all this challenge to their power and training by ridiculing this 'carnival of new therapies'. They prevented the inclusion of others into the scholarly academic institutions that they morally controlled with an unchallenged belief system - and a professional practices committee to back them up 'legally.' Too much of this exclusivity remains to this day. There was a tough fight ahead for acceptance of any new method. One therapist working in a local clinic told us that they could not mention using TA or they faced being fired. History is not kind to rebels and insurrection.

Resistance was strongest from the very psychoanalytic roots that Berne had walked away from. He taught us how to fight that resistance. He told one story where a psychoanalyst friend had a complaint about TA saying "Yours is oversimplified;" to which Berne answered, "Yours is overcomplicated." Another time Berne was criticised that his TA was "intellectualising" by psychoanalytic standards, and he had a ready answer for that too, "We respect our patients' intelligence!" Thus, he taught us how to defend TA.

If we hesitated using TA language with our patients, he reassured us "You know your patient is getting better when they start using your language."

Berne stimulated his following with the common leadership 'Us Against Them' rallying cry, polarising his difference with the psychoanalysts by saying, "Back in New York they're still driving a Model T Ford but out here in California we're driving a MercedesBenz, ha ha." (Karpman, 2006).
Steiner in his book described the competitive atmosphere of the time, "Berne...had a wonderful wit which made it possible for him to present the most radical ideas to what is probably the most skeptical, competitive, and discounting audience in the social sciences" (Steiner, 2012, p.13).

\section{Eric Berne The Scientist}

Was Eric Berne a product of the times? What did he do differently? He differed in that he was a social scientist in those times who would revolutionise, clarify and categorise human relationships and human destiny for the first time with a much clearer scientific system of analysis including the classification of over 100 'unconscious games' for the first time. His crisp objectivism was designed to overthrow the prevailing fuzzy science of psychodynamic psychiatry whose soft terminology of fantasy he referred to as "All that jazz."

\section{What Was the Bernian School of TA?}

One point that is little known is that Eric Berne was first of all a) a scientist; secondarily, b) a physician; and last of all, c) a transactional analyst. The Bernian school of TA is not about TA; it is about the scientific method that he used to invent TA, and to teach his followers how to keep inventing more TA. That was his mission.

Berne based his intellectual process on the medical model of hard science. Similar to a book in chemistry, surgery or neurology, a TA book could belong next to those hard sciences on the bookshelves in a medical library.

His model could also be used to invent other therapies at any time and place in any country.

How Berne conducted his seminars

For Eric Berne, we did not gather there to learn transactional analysis - that might happen as an aside - nor did we focus on the therapeutic applications of transactional analysis in psychotherapy. What Berne intended was to gather followers to help him make and teach new theory because he could not do it all alone, and he taught us how to do that. Later in this paper, I will give examples of the new theory made by his followers by using all of his five rules of theory-making.

With weekly brainstorming we practiced theorymaking at his weekly seminar 'think tank' in his commuter home he bought in San Francisco for that purpose for the 10 years prior to his passing in 1970 . He ran a tight ship but he could also be supportive and funny. If we ever drifted away from theory-making into casual pastiming in his living room, he would soon interrupt with his wit by saying "Hey gang, we're in danger of having an interesting evening here, so let's get some work done instead." And then to the Adult he would say "OK now let's set this up" - set up the problem to be solved. He kept us focused (Karpman, 2014). 
Berne's science

To reach his medical scientific goal, social transactions needed to be reduced to their theoretical core, whittled down by applying the centuries old Occam's Razor of Scientific Parsimony, already a standard in the hard sciences. To be accepted for publication as a TA paper, the new concept had to be finalised into diagrams, lists, charts, graphs or formulae. An example of that simplicity would be in Berne's three basic PAC circles. He believed that strictly applied scientific reductionism would place transactional concepts firmly in the company of the other respected sciences.

\section{The TA writing style}

Beyond the science, Berne went further by adding that the concepts must be teachable to others by writing them up in layperson's language, "understandable to an eight-year-old child, a Midwest farmer, and an M.I.T. professor." All three. This may still be revolutionary in TA to this day, but those were his rules. Then good ideas could easily be passed on and taught. They would not be 'lost to the dustbin of history' as the saying goes today. This packaging of the concepts into visible and easily understood language allows the current TA to be easily taught in the ITAA's four fields of transactional analysis: Psychotherapy, Counselling, Organisational, and Educational.

\section{Eric Berne's Scientific Method}

Only a few of those early therapies of the 1960s remain. Eric Berne's TA remains. How he did it is the story of this paper, as we discuss the science, the structure, the incentives, and the training that was established - and that many others did not establish.

His system required objective proof of measurement in that every transaction studied could be observable in real-time in a "photographed and tape-recorded" reality, which was his definition of reality, a reality that medical science already demanded but for which psychology was behind the times. He applied this as a strict standard to any future theory we would make. For example, in his training seminars, one was not allowed to talk of unconscious processes, because these could not be photographed or tape-recorded.

Berne was the role model. He made sure his new system could be explained and duplicated. The purpose of this paper is to fulfil that, drawn from my observations assembled from my training there for six years. All those Tuesday night sessions were taperecorded and are now permanently housed in the Eric Berne Memorial Library (2019) at UCSF Hospital Library in San Francisco.

Which ones will not survive today?

Consider now that today there also are many fine new theories emerging for their day in the sun; these will not know of the following steps to ensure permanence, and soon they may fade out, usually because of a combination of attrition, finances, disagreements, or a lack of leadership and a meeting place with easy parking. But those people will enjoy the excitement while it lasted. Here are some possibilities of leadership that will not survive:

a) Gurus with too much Critical Parent. Some movements are destined to be temporary if they have an over-controlling leader who will not let go of power. Without the democratic will of the rebel 1960s, with their slogan 'Power to the People', they will not allow a democratic system of voting and peer review that might challenge the orthodoxy and add fresh new ideas to the movement.

b) Gurus with not enough Adult. If the leader does not keep coming up with new information or elicit enough information from others for their followers to learn, or does not demonstrate enough Adult to be a role model that can solve all the situations that might arise.

c) Gurus with too much Adapted Child. Leaders could be too easy and too much into democratic ways and may compliantly postpone weekly meetings to rescue the unfortunate people who 'can't make it' regularly. Instability sets in and people leave. Berne established fixed reliable weekly meetings that could follow the movie refrain 'If you build it they will come.'

Among the many things Berne did right was imbed his work within a lasting international structure with guaranteed professional training and meetings. Almost none of the therapies of the 1960 s survived to this day. Why not? Often it was a lack of a long-term plan or structure, attrition without recruiting newcomers, or the loss of the charismatic leaders who went on to do other things. Some leaders got into trouble. Books have a shelf life. The news cycle gets shorter. Followers drop out or go on to their next best thing. Leadership gets down to just one person. The ITAA survives; this paper explains how in this 50th anniversary of the creation of the ITAA.

\section{How to Create A Lasting International Structure}

Had the dropouts followed the list below it could have given permanence to their hard work - if they believed in themselves enough and if they wanted it. Almost none of them did that. Berne knew that he had something good, a keeper. For additional permanence that went beyond the written theory, Berne followed the psychoanalytic model of creating a solid international organisation that could last over time. For any new therapies that want to ensure permanence they could follow this list used by the ITAA - if they have the great idea that people want and they keep improving it. Berne and his followers established, among others: 
1. An International Organisation. The International Transactional Analysis Association (ITAA) was established 50 years ago to ensure longevity. Also established was the European TA Association (EATA) and many solid local TA organisations like the USATAA in America. Some local organisations did not want to pay dues to a parent organisation as well and that needed to be worked out. Incentives were later added of membership levels in this new family - within a welcoming ITAA Parent structure. A well monitored website would always be available for necessary information. Dues at the right level are needed for financial survival.

2. Voting. A voting system is needed to elect officers, Board of Trustees members, and committee chairs including ethics, future planning, and conference chairs. These offer legitimate power and prestige as a motivation to continue participating in the organisation.

3. Professional Accreditation. Earning professional accreditation is a strong incentive. That needed the spontaneous creation of many available training institutes and a certification process which offered the trainers income and prestige with international notoriety and a committed following with those in their training contracts. To this permanency was added a goal of higher professional membership rankings. An aim of further professional accreditation would come with acceptance into university settings.

4. Professional Journal. A respected peer-reviewed journal is needed. The USA-based ITAA created the Transactional Analysis Journal (TAJ); the Europebased EATA established the International Journal of TA Research (\& Practice since 2018). Two journals are appreciated for diversity and choice by authors and readers, and the avoidance of centralised power in in one country. It is perhaps a sign of the times that the latter is online only and open access to all.

There are many other local journals, some remain, some dropped out. A quarterly journal was needed as incentive to create and publish new theory and therapy. Fresh new ideas maintain an organisation and ways are needed to get those ideas spread around. The Editorial Board was an incentive for people to exercise their expertise in reviewing papers and to gain an official title on the board as their reward. A membership newsletter was also needed and called The Script.

5. Awards for Excellence. After Berne's death, I proposed and it was approved that an annual Eric Berne Memorial Scientific Award (EBMSA) be established as incentive and reward for creating and publishing important new theory; and, for the individual winners, adding the incentives of notoriety and lecturing opportunities. Other annual voted awards have been added for social and organisational excellence.
6. Competent Trainers. At the grass roots level, travelling trainers and workshop leaders would spring up. Talented teachers would train people around the globe for certification. If they set up several training contracts in any city, that could keep them coming back for years and enjoy an adventurous life of travel, fame and fortune. Their programmes are not monitored and if they overcharge and undertrain or seem stringent or unethical they soon lose their trainees by rumour and attrition.

7. Annual Conferences. To all conferences, the ITAA added the Free Child fun of a Wednesday night gala membership greeting, a Saturday dinner and dance, and sometimes special luncheons. Examinations for advanced accreditation would be scheduled as well. There always has to be a membership meeting scheduled with officers reporting. Ample time must be allowed for members' complaints, questions and answers to maintain a sense of participation. In the early days of first building up of TA there were two annual conferences a year at fun resort places people wanted to go to. The local TA leaders were willing to do all the work to sponsor it.

8. Books and Publicity. For added permanence, bestselling books were written that publicised the new theory, often with the added bonus of going on publicity tours, drawing new people into the circle. Quickly, TA had two popular bestsellers Games People Play (Berne, 1964a) and I'm OK, You're OK (Harris, 1967). With those publications TA was thrust into the national spotlight, generating and welcoming newcomers seeking new insights, therapy, training and belonging.

There are several ways of making it all last through gaining permanence with:

- $\quad$ solid scientific theory;

- excellent training;

- $\quad$ happy membership;

- a financially stable structure.

In my talk at a TA gathering recently in Jamaica, with the Star Wars title of The Last Jedi, (Karpman, 2018). and speaking as the last Jedi actually teaching Eric's secrets of the 'Force', I compiled the following list of what I call Eric Berne's 'Five Rules of Theory-Making'. Outside of his TA circles, these were too original for the time and they are still mostly too original today.

\section{Berne's Five Rules of Theory-Making}

1. Don't say anything that you cannot diagram;

2. Don't say anything that has ever been said before;

3. Always apply Occam's Razor;

4. Always write it up in layperson's language;

5. Always keep inventing. 
That was it. All the early major TA theory-makers followed these rules and their ideas were easily remembered and discussed.

In my teaching of Berne's rules at selected ITAA conferences, such as in Bilbao (Karpman, 2011) and Berlin (Karpman, 2017), someone in the audience would always complain "I can't do any of those." Once, another woman responded to that saying, "It's easy. You just walk into a room and right away you have a theory about what's going on."

Original thinking and eventually theory-making gets easier if you are taught how and if you joined a similar weekly brainstorming seminar with a dedicated group whose singular purpose was to generate exciting new theory week-in and week-out - and to change the world, as was our task of the 1960s. Brainstorming is a well-known process. Successful businesses conduct brainstorming meetings routinely as necessary to stay ahead of the other businesses who are also brainstorming new ways of getting ahead. Most committees in the ITAA meet to brainstorm new ideas. Original thinking is fun and natural to people. And people like to solve puzzles.

\section{The Seminar Rules}

Berne invented strict new rules for his seminars that were set up to support the foundational mission - we meet to create new TA theory. The meetings were complete - purposeful for the Parent, objective for the Adult, and fun for the Child. This three ego state 'bullseye' would keep the attendance high.

Berne, a group therapist, had his own 'think tank' group now in his new commuter home in San Francisco (his primary home was in Carmel to the South). The living room and dining room spaces were combined with seating to accommodate up to 30 people. Everyone had a good view of the blackboard which was placed to the right of Berne. Every meeting was taped with Claude Steiner handling the recorder. There are over 100 tapes now stored at the Eric Berne Memorial Library at the UCSF Library in San Francisco with a newly compiled package of selected tapes in eight CDs with photos and identification of seminar members additionally available (Karpman, Steiner and Ricciuti, 2016). A wealth of personal and professional information, letters and photographs have been compiled by Carol Solomon on the Eric Berne Memorial Library website. Many interviews of colleagues and seminar members were assembled at the time by Henry and Liz Jorgensen for their in-depth biography Eric Berne, Master Gamesman (Jorgensen and Jorgensen, 1984).

One of the seminar rules was that anyone speaking of their new idea was required to get up and walk to the blackboard and diagram it. Berne frequently drew diagrams on the board next to him. The blackboard was the centrepiece of his seminars. People were encouraged to spontaneously walk up to the blackboard and write and draw their ideas and they frequently did.

If from the back of the room a hippie on a love mission would emote "Love is in the air, love is everywhere!!" Berne would immediately say "Go to the blackboard and diagram that!" If the person could not do that, they would be kicked out of the seminar, because they were saying something that had already been said before and they could not diagram it - thereby breaking Berne's first two rules of creativity. Berne once said TA was like a three-scoop ice cream cone "If it gets too warm it melts." I was kicked out of the seminar for a week once by twice bringing up the word "dependency". That word had "already been said before" (Freudian) and could not be "photographed and tape-recorded" and belonged to another school. Looking to our past was not our mission, we needed a clean cut to make something entirely new.

Berne had a wit but also ran a tight ship. No drinking or smoking allowed. We started and ended on time. There was always play time afterwards set aside for the Child fun, where we would invent a group game or go out together on 'field trips'. Elections were settled by a broad jump. Other serious scientific meetings probably did not do this.

Equality was the standard for the membership. A presenter had to first write the unsolved question on the blackboard and then we would all focus on trying to solve it, hopefully by stimulating new TA theory. Presenters were not allowed to "talk down to the audience" by "having all the answers" because then the audience would not be equal to them, nor would they have been needed to solve something. Solving puzzles was the goal of the seminar and not just listening to old-school case studies. If the direction was unclear Berne would often get us all back into our Adults by saying, "OK gang, let's set this up and solve something." It was a working group, not a social group.

Berne kept interest up by often using the seminar to get feedback by reading the latest writing from his new book. This was a leader demonstrating how it gets done, the 'Here's How' in the original script matrix. He was inspiring and frequently dropped pearls of wisdom such as "The Child is the most important ego state and all the other ego states are set up to protect it." Once he read to us the names of all his new trading stamps: blue for sad, red for mad, grey for fear. When he spoke of a 'mauve' stamp, I questioned it from the audience, and he replied with his wit, "I put that in there to hook the Blemish players." Everyone laughed. He was an interesting man.

A discussion of the rules of the seminar and Berne's rules for theory making can be found further 
summarised in the back of my book A Game Free Life (Karpman, 2014).

\section{Who Were Berne's New Theorists?}

Who made up the new theorists? Professional background or gender did not matter; just anyone using their imagination could come up with major new theory, and they did. We were there to learn that brainstorming can solve a problem in TA. Brainstorming creates ideas - which can be developed into concepts and then into theory and then into writing and then into published articles and then into lectures in conferences.

Were the new theories created by research? Yes, we regularly discovered new ideas for psychotherapy - but it was not traditional research. It was 'brainstorming research'. Another kind of research. There was no time for the double-blind studies to prove or disprove something. There was a job to do and the aim was to get it done each week by the people in that room with the added incentive to have it published immediately in the next issue of Berne's Transactional Analysis Bulletin - and not two years later which was the old tradition.

His system to create scientifically formatted theory, presented in this paper, could be duplicated in any city in the world if a charismatic leader with helpers met weekly and followed Berne's seminar brainstorming rules.

After Berne's untimely death in 1970, the ITAA trustees passed a resolution that an annual Eric Berne Memorial Scientific Award (EBMSA) be established following my suggestion (as mentioned above), with a permanent plaque and a $\$ 400$ financial award, to be voted on and given annually in celebration at the annual membership meeting. The Editorial Board then constructed strict new rules for what is an original theory and what is not, to ensure that we never give out a 'popular' award. An award speech would be given and published in the following January TA journal.

The following are examples of early EBMSA winners selected from those who trained with Berne, some who later created their own think tanks, or were directly influenced by Eric Berne's 202 study group. These theorists are listed as examples of those who strictly followed all five of Berne's rules and were subsequently rewarded with professional recognition in science. Of course each article has its own scientific diagram.

1971 Steiner. The Script Matrix, a triplex ego state diagram of parents delivering scripting messages to their child (Steiner, 1966).
1972 Karpman. The Drama Triangle, a triangular diagram of the three switching roles of Persecutor, Rescuer and Victim during games (Karpman, 1968).

1973 Dusay. Egogram, an intuitive bar chart measuring the relative strength of five ego states in manner and facial expression (Dusay, 1972).

1974 Schiff and Schiff. Passivity and Discounting, two lists of four ways of passively discounting problem solving during agitated states (Schiff and Schiff, 1971).

1975 Goulding and Goulding. Injunctions, decisions, and redecisions, a new redecision therapy including a list of 12 injunctions and script decisions made by a child under family stress (Goulding and Goulding, 1976).

1977 Kahler with Capers. Miniscript, a new treatment model with a diagram based on the script reinforcing power of a list of five counterscript drivers. (Kahler with Capers, 1974).

1979 Karpman. Options, a confronting ego state diagram showing 24 positive ways to cross transactions to escape from games (Karpman, 1971).

1980 Mellor and Schiff. Redefining Hexagon, a sixsided diagram to explain discounting behaviour (Mellor and Schiff, 1975a, 1975b).

1981 Ernst. The OK Corral, a quadratic chart showing how four life decisions are based on one's four OK/OK +/- positions (Ernst, 1971).

1982 Erskine and Trautman. Complex diagrams for the racket analysis of games. (Erskine \& Zalcman, 1979).

1983 James Self Reparenting A system for self reparenting, with diagrams (James, 1974).

1984 Levin. Cycles of development, lists with diagrams of seven developmental stages with tasks that will recycle throughout life (Levin, 1982).

In his prior writings, Berne had demonstrated diagrammaking by example in all of his works; here are some examples - there are many others:

- Relationship Diagram (Berne, 1961, p.130);

- Structural maps within organisations (Berne, 1963);

- The list of over 100 social games (Berne, 1964a)

- Diagrams of ego states and crossed transactions (Berne, 1964a, p. 29),

- The list of Four OK Positions (Berne, 1966, p.270);

- The list of six levels of Time Structuring (Berne, 1966, p.230); 
- The list of Six Basic Hungers (Berne, 1970, p.210);

- The list of Six Time Scripts (Berne, 1970, p.166),

- Game Formula G (Berne, 1972, p.23).

\section{The Lost Science of Eric Berne}

But then where did it all go? Today's TA barely looks like Berne's social TA. How could that happen? It is said that the further one gets away from the source, the more the influence is lost. If one reads current TA literature today, we see very few signs of Berne's strict rules of diagram-making and tight scientific writing written in layperson's language. We do not see popular new books published on TA. Five decades later the transactional analysis that attracted people from the bestseller Berne's Games People Play and Harris' I'm OK, You're OK hardly seems recognisable anymore. More often it looks like post-Freudian writing. Let's look at some of the reasons.

\section{The 202 Seminars Were Replaced by Training Standards}

The weekly two-hour time allotted for the 202 seminars was designed for brainstorming new theory. That continually breathed new life blood into TA in a research and development effort. But TA moved up from the inspired change-the-world Child to the practical Adult, and then into the stricter Parent to keep things in order. This inevitable progression model is diagrammed with the Parent Percolator (Karpman, 1975b). Members now had to give their weekly time over to the needs of Parent ITAA Training Standards Committee to prepare for their credentialing exams. Training Standards ended the 202 in most cities. Sometimes it allows for new theory ideas.

Many centres were not able to meet on a weekly basis because of home and schedule conflicts. That was not an issue with the randomly sorted membership in Eric Berne's training group with the entire San Francisco Bay Area to draw from.

Basic TA theory and practice (what "had already been said before") had to be learned for the exams instead, as the next step for professional certification, with a strong new interest now in belonging to the ITAA family with its many benefits, but pre-empting the previously organised focus on new theory making.

\section{The Originators "Did Their Own Thing"}

'Do your own thing.' Fritz Perls permission posters and bumper stickers saying 'question authority' were the mindset of the 1960s. So Berne's trainees scattered out on their own to individualise themselves, which was the order of the day, and develop their own important new forms of psychotherapy, with variations that Berne could not have imagined by himself. Many of these, like the training centres established by the Gouldings in nearby Mt. Madonna and by the Schiffs in Oakland, still included creating and publishing very important new theory. Therapists travelled from all over the world to reside and study at these centres. People used Berne's theory to develop and demonstrate their own systems, but often did not teach new trainees the Berne theory rules behind how they did it.

There were also the TAers who stayed on as the classical school and were quite content to continue with Berne's 'game and script' TA. The 202 seminars continued to meet weekly at Dr. Dusay's house in San Francisco after Berne's passing. Many TA trainers were still mentioning Berne's principles, but the effects did not show up in the TA literature as often as previously. All training centres encouraged the publication of new ideas.

\section{Natural Decay, Entropy and Attrition}

Time naturally takes its toll. Natural attrition was replaced by new blood which had no roots to Berne and the 'Great Pyramids' of yesteryear. A new generation usually wants something new of their own. Individuals have agendas. Original principles were no longer known, taught, or important to the newer members, most of whom just wanted to learn to be better therapists and get professional certifications to practice. To some there seemed to be enough TA theory invented already, maybe too much. Training became costly and time-consuming with people dropping out.

\section{Freud's 'The Return of The Repressed.'}

Berne's agenda was to overthrow the dominant Freudian establishment but like the Star Wars The Empire Strikes Back, a Freudian TA insurgency gradually fought back to hijack Berne's TA. This essentially went unchallenged because of Berne's early passing. The Neo-Freudian platform of intersubjectivity, fantasy, transference and projection took over. (Karpman, 2006). This soft language was never allowed in Berne's seminars, but the Freudian systems were mentioned in Berne's earliest writings, which was used to attract a wider interest in TA in the Relational school.

What happened also reflected the dominance of psychodynamic approaches in the wider psychotherapy field. Many newcomers to TA were bringing the relational approaches with them and were attracted to the TA clarity, training and organisational benefits. Many TA therapists today now prefer this Neo-Freudian relational TA and are glad to have Berne's early theory available to refer to.

However, others see that the official TAJ is often published with no Bernian style diagrams at all, with none of the simple crisp language, imagery and scientific diagrams. Often, the predominance of the references is assigned to Neo-Freudian authors and 
other non-TA authors. At times there were articles with diagrams submitted and accepted, but they were only found tucked into the back of the Journal because they did not fit in with the 'newer TA'.

Many members stopped reading the journal and left the organisation because it was not the TA that they loved with its racy insights into what people do with each other. That TA was useful to the $99 \%$ world population, now the new TA is mostly useful just for the $1 \%$ therapists and their clients. But the relational therapy is very successful in the hands of therapists who prefer the emotional experiences of that method.

\section{The ITAA Organisation Did Not Preserve Berne's Methods}

The ITAA stayed passively open to change, re-elected new officers and committees every few years, the Board of Trustees met only once a year for a day or two, and often the continuity of what was important fell between the cracks. Oversight gets lax in a volunteer organisation. Egos get involved. Power and agenda step into a vacuum. But the ITAA also made many more things permanent, like the important Training Standards Committee and examinations for TA credentialing, the rigorous peer review of articles for the TAJ, the reliable scheduling of the annual conferences, and other benefits. And there is a central office with long-term staff that that are known and reliable.

Successful organisations thrive on research and development for new ideas and TA had an established genius system set up, but no-one locked it into place. Original TA articles appear regularly in print but the strict five rules of creativity of Eric Berne did not. Some articles seem like 'old school' articles. Berne's brilliant TA ideas research model was left to entropy and fade into history.

\section{5. "Always Keep Inventing"}

But most of the originals did stay with Berne's system for creating new theory. Many created their own institutes devoted to therapy and training but also to brainstorming the discoveries from that therapy and writing it out in line with Berne's five rules.

A demonstration of Berne's Fifth Rule, that emerged from Berne's weekly 202 brainstorming sessions, was the drama triangle idea I invented back in 1966. It got popular, even went viral, and soon it was necessary to 'mark out my territory'. It became 'my baby' and necessary new variations had to be invented as the need arose. So I will demonstrate some examples of Berne's Fifth Rule of "always keep inventing" as follows, adding explanations of why each improvement had to be developed.

The drama triangle became popular and spread in use quickly - but only because it incorporated all of Berne's five theory-making rules, plus I gave it a catchy diagram and a catchy name with 'kid hooks'. Had I just written a typical long, cumbersome and wordy article explaining three roles it would have gone nowhere, just like so many other good ideas buried in such articles that do not get the recognition they deserve. The beginning rules of theory-making are not widely enough known; a remedy for which is a purpose of this paper.

As the history goes, the drama triangle began by chance one day when I playfully wondered what would happen if ... I could make a single diagram that could incorporate the triple fake moves used in basketball and in football, both interests of mine? Who thinks of thought experiments like that? The seminar groups left me in the mood of playful creativity. I had a favourite three-part move myself that I used in basketball to get free for an easy lay-up. With a lot of paper on hand I doodled combination diagrams for 30 pages and eventually came up with the drama triangle. On page 29 I had a fourth position on the triangle, a puzzlemeister Trickster who was pulling the strings, moving all the action like a puppeteer. But Occam's Razor required more reductionism so I incorporated switching action into arrows which had to be condensed into a triangle. I gave it a catchy name to hook the Child and it caught on and went viral with over 100,000 references found on Google (Karpman, 1968, 2014). Berne referred to it as Karpman's Triangle and that name caught on too.

To me at the time it was just a throwaway idea, a sports diagram I put on my office blackboard for two years and only used with patients. Then one evening when I showed it to Eric Berne he lit up and said "Write that up Steve! People are going to quote you for 200 years." The rest is history. How did he know? It is now 50 years and counting. (Karpman, 1968, 2014)

\section{Need It, Invent It, Teach It}

The longer someone stays with their idea, the more there will be needed to improve the idea, and a greater need to teach it and make known the improvements of the idea (or one can ruin it and make it overcomplicated).

We see continuing improvements in the fields of contemporary abstract art where an artist may make thousands of drawings to finally get a signature image of their own, to then play out all the variations of their idea to stake out their territory and keep the imitators away. Picasso went through many years of reinventing himself in the different eras of his life. Eric Berne invented a disruptive signature idea of his own and he kept inventing the necessary variations of the idea throughout his life and teaching it to others. In the pages ahead I will demonstrate variations of the drama triangle and why they had to be invented and useful enough that it needed to be taught. 
The Social Level Drama Triangles

a) Role switches

The Original Drama Triangle first illustrated the roles and switches in a game (Figure 1). This included all six switch possibilities of the Trickster who was cut out of the earlier four-sided model. There are no transactional lines, only switches among roles. The roles are not ego states.

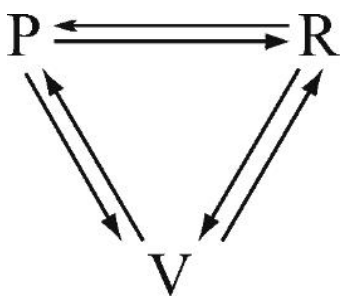

Figure 1: The Original Drama Triangle

However, over time with popular usage and with the ease of drawing it on a blackboard, others began drawing it with three straight lines only - without the arrows, and pointing up like a pyramid. The triangle became very helpful in rising above games by naming the players and the agendas. But people did not see the dramatic switching, and now the triangle was only representing dysfunctional roles. That vacuum led people to erroneously tack on their own fourth role, reversing the rule of Occam's Razor, like the Adult 'observer' role and others who do not belong, embedded within the arrows, because they were never personally emotionally enmeshed in the gritty dynamic switching that creates the drama itself.

Further, over time, people did not know that there were theoretical reasons for having the Victim in the powerless one-down position at the bottom of the triangle. Berne initially suggested to me that I place the Victim on top, in the power role, initiating the games to get their payoff, which was intriguing, but the onedown powerless position was popular at the time and it worked best for me visually. Forgotten too was that the triangle had to be drawn equilaterally to standardise the switching time and distance between the roles. I needed to clarify that on my website.

Once a new idea gets attention the originator needs to protect the original concept but without discouraging new improvements and applications. I kept it open source, free to all, with no royalties.

\section{b) Add game switches}

The Transactional Switch Drama Triangle (Figure 2) was introduced. To keep going with this story of invention, and for ongoing protection of the integrity of the idea, a quick clarification was needed to establish where to include the transactional lines. This was solved visually by placing the transactional arrows along the inside lines of the triangle. Then the switch lines were added as long circular arrows on the outside of the triangle. This clarification of the two sets of lines was needed to head off confusion that might occur.

As an example, Figure 2 illustrates the game of I'm Only Trying to Help You. The Victim is seen in transaction with the Rescuer begging "You're the only one in the world who can help me," and the goodhearted Rescuer responds with "Yes, I can take care of all your needs." Next, to complete a game, the switch occurs (curved line), and the Victim moves up to Persecutor becoming critical of the imperfect help, and the Rescuer is switched down to become the new misunderstood Victim - and they both got their payoffs.

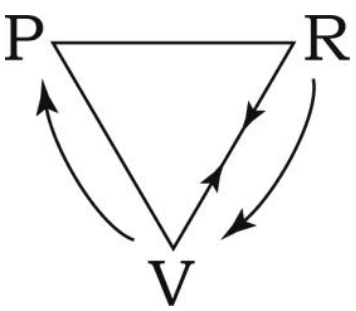

Figure 2: The Transactional Switch Drama Triangle

That diagram is used to illustrate transactions and switches. Now let's use that same diagram to illustrate role playing.

c) Role playing

In the alcoholic game, the alcoholic starts out in the role of the lonely and bored Victim. They then move up to Persecutor to shift their own unhappiness onto others by getting drunk and unpredictable. Then they move over to the repentant Rescuer role to make it all OK to everyone if given "one more chance". But eventually that is not satisfying so trading stamps (Berne, 1964b) are collected and cashed in with a return to the Victim role, thus starting the next game cycle, all over again, the same way. (Karpman, 2014).

Additionally, this triangle can show that each of the three roles can be taken up by different people. In a court room drama, you are a victim, your lawyer is the rescuer, and the opposing lawyer is the persecutor. In literature and dramas, the victim would find many heroes and villains along the way to multiply the drama.

The alcoholic assumes the troublemaking Persecutor role. the Rescuer takes on the classic codependent role of the martyr giving up on personal goals, and the Victim roles are occupied by the children taking the roles of Adult Children of Alcoholics (ACA). These classically go out into the world one day as grown-ups distributed among the same three roles of the family drama triangle: the ACA Scapegoat role as the new troublemaking Persecutor; the Mascot and Hero role as a Rescuer prove to the world that the family was not dysfunctional; and the Lost child role means living life as a Victim, numbed out and unrealised. 
d) Add the positive

As shown in the Positive OK Triangle (Figure 3), I next needed to include the positive orientation of TA. Berne always taught that people could choose to use each ego state energy in a positive or negative way so I would illustrate the same $+/$ - principle with the triangle to bring it in line with TA thinking.

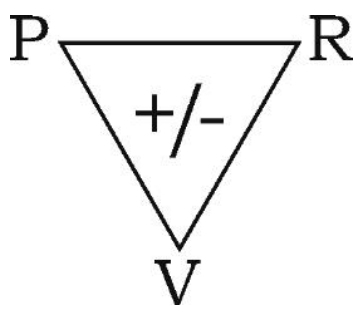

Figure 3: The Positive OK Triangle

\section{e) Add the escapes}

The Escapes Drama Triangle (Figure 4) came because, soon after learning about the drama triangle, people would ask "Then, how do I get out of the triangle?" The escape triangle shows that escapes could be managed from any of the three positions. This was later expanded to place the escapes within a different diagram, the Ernst OK Corral (Ernst, 1971; Karpman, 2014).

\section{f) Try transaction lines}

The Sex Games Triangle (Figure 5) needed to be developed in response to questions about whether the drama triangle could find its way into bedroom role playing which involved transactions. I needed to develop the use of the arrows in a different way to represent sex games consciously or subconsciously arranged between the players. For instance, the concerned Rescuer will take an 'Appeaser' role to placate the tough Persecutor, who in turn will see the Rescuer as 'too easy' and take advantage of this by doubling up on the narcissistic 'User' role. Then they could switch sides and play it a different way. There are three games to choose from.

\section{g) Three forgiving motivations}

The Compassion Triangle 2.0 (Figure 6) came next as I asked the question of what would happen if ... I could show in a diagram what had become apparent in clinical practice, that all three drama roles are always

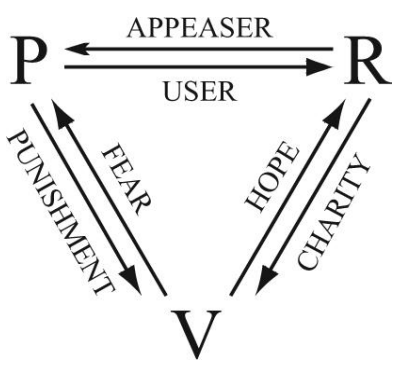

Figure 5: The Sex Games Triangle.

present in each person and at different levels of effect and awareness and use in the game, each exerting their own influence on the outcome? This reflects basic TA theory that all three ego states are always present in each person - and as visually proven in the egogram.

So we established a sharing exercise with couples with a new compassion triangle. Each partner would take turns to acknowledge all three $\mathrm{OK}+$ motivations in themselves, and then all three OK motivations in the other person, and this would be a way of giving and receiving forgiveness and a way out of the game with the new shared feelings and understanding. This offered six new choices for discussing the game (Karpman, 2014). Couples initially need to refer to the diagram in Figure 6 for clarification as a way of getting started. (See Karpman (2019) for more information on how to conduct this activity).

It was later established that all three roles were triggered simultaneously for ancient survival reasons, at an instinctual level, as explained below in the Evolutionary Level of the Darwinian Triangle 3.0 (Figure 21).

People will say they got help from the drama triangle by identifying what is happening - and then they get out. But they rarely consider, nor were they interested in, whether there were OK behavioural reasons why people stayed in the game and that they could be willing to talk about it, and get relief, and stay with the person. The compassion triangle provides a threesided reason of why the game is played. The drama triangle shows behaviourally what is happening, and who it is happening to. The compassion triangle adds the third option of why it is happening.

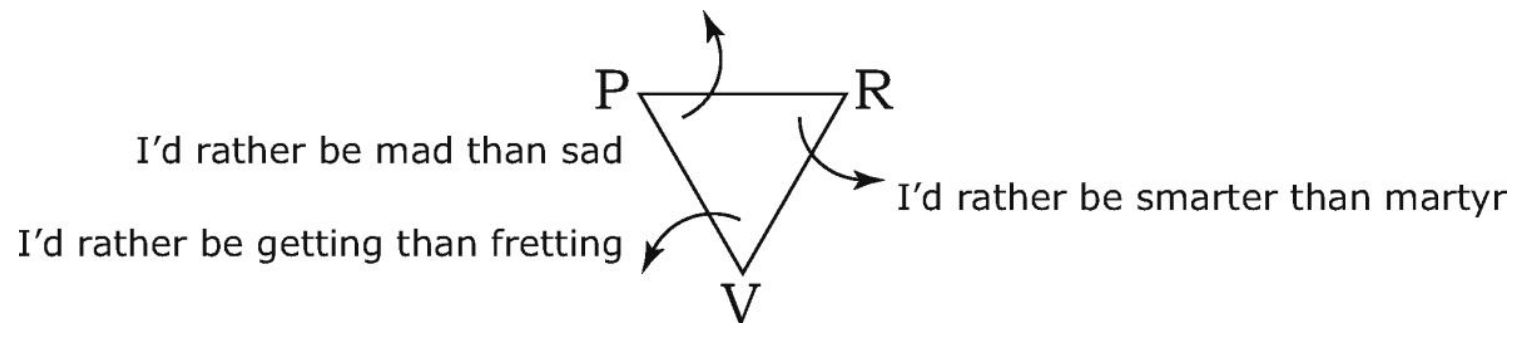

Figure 4: The Escapes Drama Triangle 
The centre number refers to the "10\% solution," that says that at least $10 \%$ of anything a person says is true, $10 \%$ of anything a person says is false, and at least $10 \%$ of the world's population would agree with that, and $10 \%$ would disagree with that. This is useful in couples' therapy (Karpman, 2014) for a person to admit partial culpability.

\section{Give Apology Give Appreciation

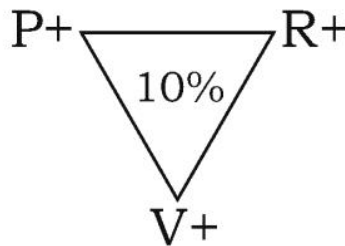 \\ Give Sympathy}

Figure 6: The Compassion Triangle 2.0

\section{h) Add the hidden selves}

The Submerged Compassion Triangles (Figure 7) is the compassion diagram but with a different visual impact to better illustrate that there are unseen reasons behind the game, by drawing it with a submerged iceberg diagram. (Karpman, 2014). For example:

Office Example. Using an example in an office situation using just one triangle, the boss only looks like a Persecutor (above the surface) when strongly criticising an employee, but secretly underneath, the boss is the Rescuer trying to help the person learn their job better and to keep them from being fired, and also a Victim because their own job is at stake if the office does not perform as senior management expect it to. There are three levels behind every action.

Couples' Example. Using the two submerged triangles diagram, a couple keep fighting because they can only see the other as a Persecutor (above the surface) and have to battle against this to get their point heard. Things would get better quickly if they looked beneath the surface and saw the other's Rescuer motivation (Appreciation - trying to fix things) and Victim motivation (Sympathy - wanting to be understood during a battle). Throw in an Apology each way and this could ease the tension behind the fighters, as also explained in the Compassion Triangle.

Bad Doggie Example. In a canine example - yes there is dog drama too - a barking dog on a leash outdoors was seen as an annoying Persecutor and a worry about the neighbours (above the surface - and all the owner could see), but secretly, doggie is a Rescuer, barking to protect their owner, and secretly a Victim, frightened they are on a leash and unable to provide their own escape if a predator dog comes after them from around the corner. Checking out for all three roles allows a sympathetic way out of this accusatory game of Bad Doggie.

Conversely, there are three ways the dog could see their owner in that situation - as a Victim - needing their protection, as a Rescuer - always there to love them and feed them, and as Persecutor - being harsh to them.

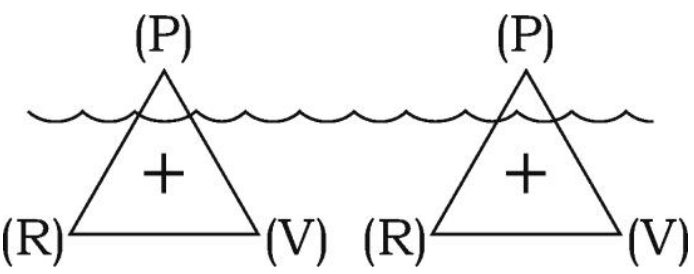

Figure 7: The Submerged Compassion Triangles

\section{The Psychological Level Drama Triangles \\ i) Add feelings inside the triangle}

The observed social behaviours have already been put on the outside of the triangle. The next step in the development of the drama triangle was to take a look inside to see if use could be made of the blank interior spaces inside of the drama triangle. This proved useful in giving visual space for the psychological level of TA and it attaches to the same diagram as the social level of TA so both levels could be seen in one diagram, just as both levels exist together in contact within us. The result was the Inner Self Drama Triangle +/- (Figure 8), where the three PRV roles are tucked into their respective corners and viewed with the characteristic TA positive versus negative way of using energy.

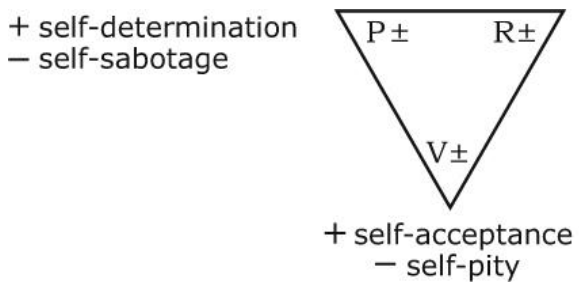

self-love + self-delusion -

Figure 8: The inner-self drama triangle +/-

Figure 8 spells out the treatment possibilities of converting the negative energy of these inner roles into their positive energy counterpart. In one example it would be to convert the aggressive energy of the inner Persecutor from negative self-sabotage into the positive energy of self-determination and empowerment.

As an alternative use, in a depressed state, these are reversed and the positive attitude is converted into the negative attitude. For example, in the Victim role, positive self-acceptance $\left(\mathrm{V}_{+}\right)$could give way to negative self-pity (V-) during depression. This could then lead the other corners to enter into self-delusion (R-) and self-sabotage ( $\mathrm{P}-$ ) and needing treatment. 


\section{j) Add internal sequences}

What else could we do now that we have started filling in the interior space of the triangle? In Figure 8 we have already given a way of illustrating our internal positive and negative energies and feelings. Next we could use the interior spaces to illustrate sequences that shift around inside us during our private inner games of stress and relief and back again.

This led to the Addiction Triangles (Figure 9) (Karpman, 2014), as an illustration of a predictable movement series of inner roles, not transactions, occurring inside the self. We can add numbers inside the triangle to represent stages of a predictable sequence.

This addiction triangle illustrates a sequence of inside games played during times of food, drug, alcohol, cigarette or behavioural addiction and can follow the pattern illustrated for a food addict: 1. The food Victim feels loneliness and boredom; 2 . Rescues themself at the refrigerator, but over-eats, feels guilty, and then shifts over to 3 . and Persecutes themself for having slipped, then returns to the Victim position 1 to start the cycle again on another day or again several times that same day.

The rotation can go in the other direction too and from any starting point. The domestic cycle of violence usually follows a predictable pattern on both the social level and psychological level. (Karpman, 2014).

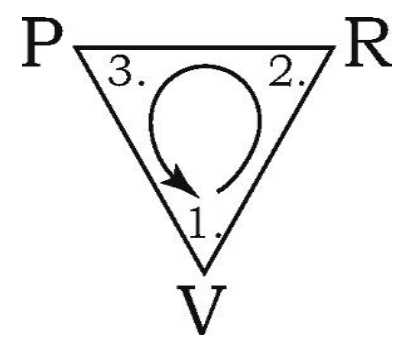

Figure 9: The Addiction Triangle

\section{k) Add Freudian dynamics}

We can use the drama triangle to show the direct link between the psychoanalysis system and the transactional analysis system, using the Freudian Triangle (Figure 10). Both disciplines have a threesided dynamic energy system that fit together in the drama triangle.

In the Freudian triangle we place the unwanted and suppressed id into the Victim role, but it finds some outlet with the friendly Rescuer ego who can help it by converting some of the raw energy into real use in the outside world, using the many ego mechanisms of defence such as sublimation, reaction formation, suppression, etc. However, both are under pressure as illustrated by the ever-present superego, the watch- dog Persecutor controlling and limiting excess, as illustrated.

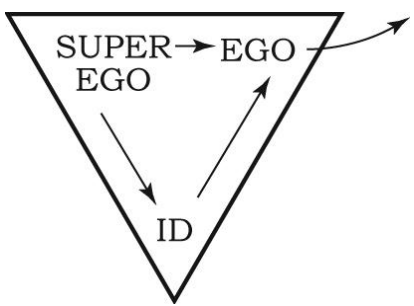

Figure 10: the Freudian Triangle

\section{The Script Level Drama Triangles \\ I) Add the family triangles}

To follow up on the above Freudian Triangle, we can ask if we can also use the drama triangle to connect to Freudian transference theory, by showing in one diagram a direct link from the past to the present. A new diagram was needed, in which a small drama triangle representing the early family games is placed inside the larger present-day drama triangle. Arrows can be used to show the direct connections between the past and present, which can show up as a transference reaction. This became the Transference Triangle (Figure 11).

The diagram illustrates both script and game in a single diagram for the first time in TA writing. By using connecting arrows, the back-and-forth dynamic between the past and present can now be shown in one simple teaching diagram. For convenience it can be called the Transference Diagram but it also represents Berne's memory snapback rubberband (Berne, 1960-1970; Kupfer and Haimowitz, 1971) and Berne's (1961) palimpsest. In here one can place the origins of the games from within a family triangle.

We can also change the format of the lines inside to indicate whether the process is blocked, fluctuating or overly-connected (Karpman, 2019).

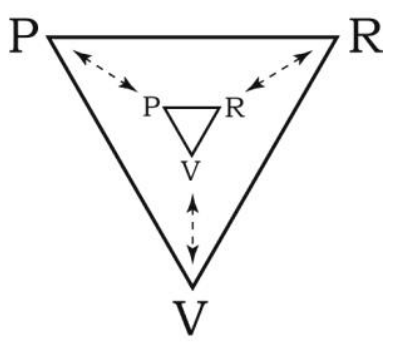

Figure 11: The Transference Triangle

m) The Redecision Triangle

Moving a step further from the theory model into a treatment model, we can use the new nested family triangles to look at the injunctions and decisions used 
in the Goulding's' therapeutic script redecision process (Goulding and Goulding, 1976), as shown in Figure 12.

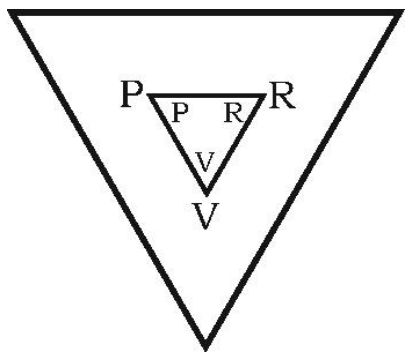

Figure 12: The Redecision Triangle.

Script decisions and injunctions under stress would have happened during a family game. That game would have a name right out of Berne (1964a) and have happened at a time and place that could have been photographed by the participants. We will call this the Script Game occurring within a Script Scene.

In the redecision treatment process, the (regressed) child is encouraged in serial Gestalt regression steps to relive a traumatic early memory. We can place those psychological level feelings of that child on the inner sides of the small family triangle.

When reliving the scripting game, we can ask the first question "How did you feel at the time?" If the child felt rejected and alone as the Victim, the next question could be "How did you feel about the world at the time?" The answer might be "No one will help me. I am all alone in the world," and a self-protective Rescue decision and life position may be made "I will have to get along by myself." The next move finalises the protective wall by moving over to a fixed and limiting Persecutor decision with a lifelong Don't be Close or Don't Want script decision as an injunction. Later in life, by replaying the script game with a suitable partner, this protective position can be continually reinforced, and serves to prevent a triggered reexperiencing of the repressed trauma (Karpman, 2014).

Additionally, we can make use of the outer side of that child's triangle to show their social level relationship with their parents and possible reasons they have for accepting the injunctions: i.e. surrendering as an overmatched Victim; granting the parents their wishes as Rescuer; and using the script injunction against them as a Persecutor by sabotaging the parents' hopes for a successful child in the world.

\section{n) Add script reinforcement}

We can use the inside of the drama triangle to modify the script reinforcing miniscript (Kahler, 1974). In the Miniscript Drama Triangle (Figure 13) the reinforcing process of the script begins in the lower left corner in a Victim position, where one holds their unmet needs, stamps and rackets (racket, because it is a game triangle). In an attempt to repair this feeling, one moves up to Rescue oneself with the driver position of I'm OK if... However, all five drivers are built to fail and one inevitably falls to the Persecutor stopper position, where they are met by some of the redecision injunctions either from others or within oneself. Failed and despairing, one slides back over into the Victim position. This happens over and over again, sometimes within seconds, in a never-ending script reinforcing, repetition compulsion.

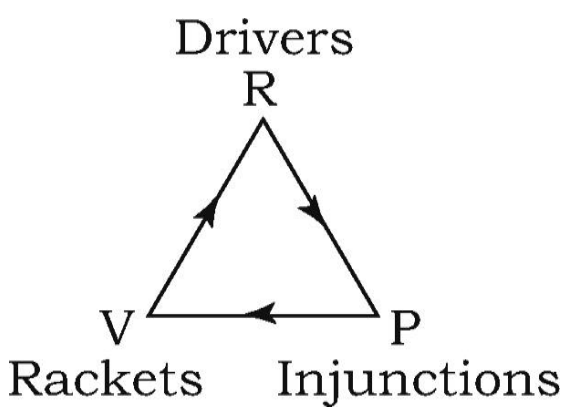

Figure 13: The Miniscript Drama Triangle

\section{Five Split-Level TA Teaching Triangles}

o) Add teaching diagrams

To keep the Fifth Rule going by finding useful new combinations of the drama triangle, we next ask what would happen if we wanted to tie together various threads of TA theory into an easily teachable all-in-one game diagram using the drama triangle, resulting in Figures 14, 15, 16, 17, 18.

\section{The Four-School Teaching Diagram}

Figure 14 organises four-in-one different approaches to TA theory, bundling Berne (rackets), Kahler (drivers), and Goulding \& Goulding (injunctions) in an all-in-one Karpman (drama triangle) script teaching diagram.

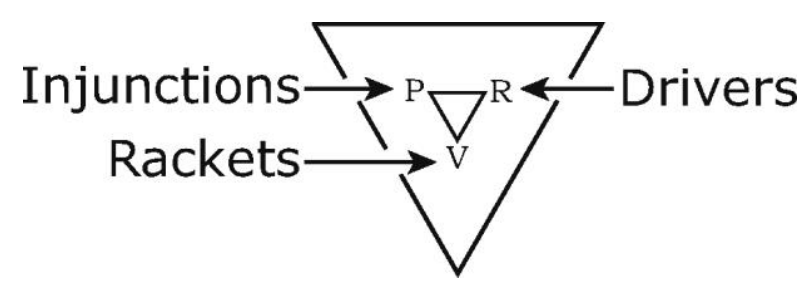

Figure 14: The Four-School Teaching Diagram

\section{The Three TA Levels Teaching Diagram}

Figure 15 focuses on three classic levels of TA study. On the outside, place what is in the here-and-now at the social level; inside we place the unspoken racket feelings and beliefs at the psychological level, and deeper inside we place the first origins of roles and games at the script level. 


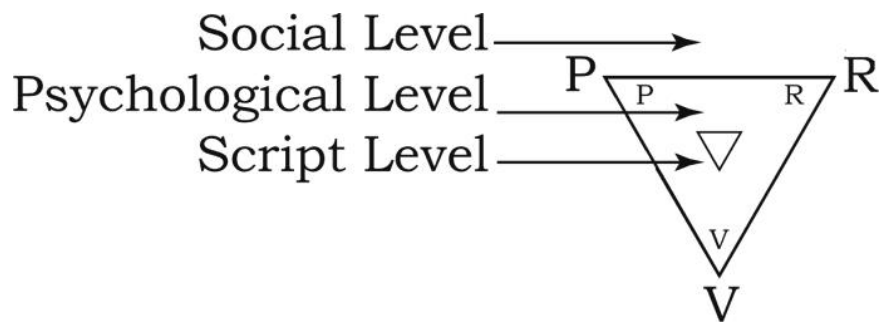

Figure 15: A Three TA Level Teaching Diagram

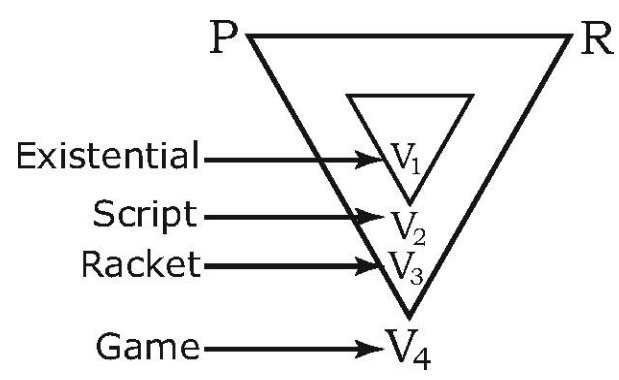

Figure 18: The Existential Script Triangles
The Talking Level TA Teaching Diagram

Figure 16 is an experiential diagram of what you feel you are actually able to say during a game, and what you dare not say during a game, and, deep inside the triangle, what is suppressed and unknown that you are unable to say during a game.

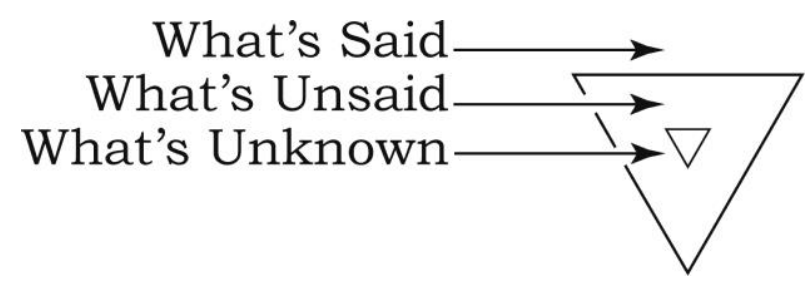

Figure 16: The Talking Level TA Teaching Diagram.

The Three-Consciousness Teaching Diagram

Figure 17 illustrates when we integrate more Freudian theory into the drama triangle. Borrowing from the Freudian model again we can usefully illustrate three levels of consciousness: conscious, subconscious, unconscious.

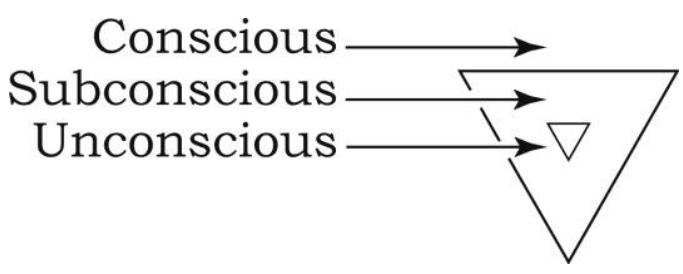

Figure 17: The Three-Consciousness Teaching Diagram

\section{The Existential Script Triangles}

Figure 18 is another nested script diagram, this time with numbered sequences that start with the nonverbal existential position acquired upon entering life, or earlier, and how its deep influence is followed through three more stages of life into the present, called the existential path of the Victim.

Alternately one could come from the other corners; a Persecutor born with too much aggressive energy who meets constant opposition in life, or a Rescuer born too giving who gets betrayed or constantly taken advantage of in life.
The Biological Level

p) Add a biological level

We have discovered that the three-part energy system of the drama triangle may hide wider universal truths. What if the three-part energy system could apply to the cellular transactions and dynamics within our biology? So let us go a step further and place an even smaller triangle inside the family triangle, creating the DNA Roles and Cellular Transactions diagram (Figure 19).

This suggests a biological level triangle in two ways:

- $\quad$ The DNA Level: the three-cornered energy model is universal and here will be explored as applied to the biological level. It works for three roles at the DNA level, where the Persecutor DNA damages the hopes of evolution and may eventually end the species, the Rescuer DNA level provides the future of better evolutions, and the Victim vestigial inert DNA just contributes maintenance or less.

- $\quad$ The Cellular Level: next, we look at transactions between cells, not roles, in a cellular dynamic at the cellular level. Using the example of the chemistry behind the use of SSRI (selective serotonin reuptake inhibitor) medications, the Rescuer cells continually will re-supply serotonin, the passive Victim cells will continually provide the reception, and the Persecutor cells are necessary for the restriction ensuring that there is neither over-supply nor over-absorption of the serotonin molecule.

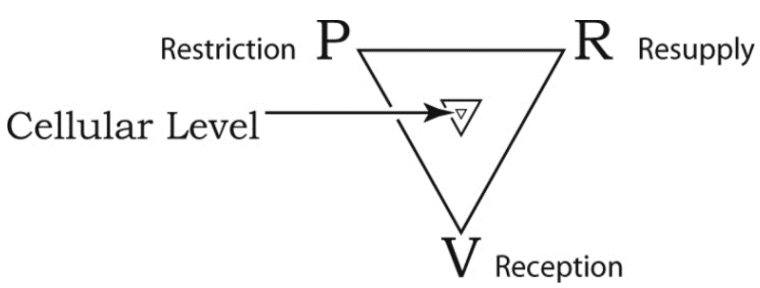

Figure 19: Biological Level Transactions 
The Evolution Level. Darwinian Scripting

q) Add an evolutionary level

For many years I searched for proof of the valuable compassion triangle which took the position that all three roles would be triggered at once during any game in every one of the players.

Then I saw one evening on a nature program on TV, a baby elephant was threatened by a tiger and the larger parent elephants made a circle around the baby to protect it. Then they scared off the tiger. Aha! That was it. All three roles in the drama triangle became apparent and proved to be instinctive and necessary for survival of the new infant, to go on to create a next generation, and the next. Hence was invented the Darwinian Triangle 3.0. (Figure 20).

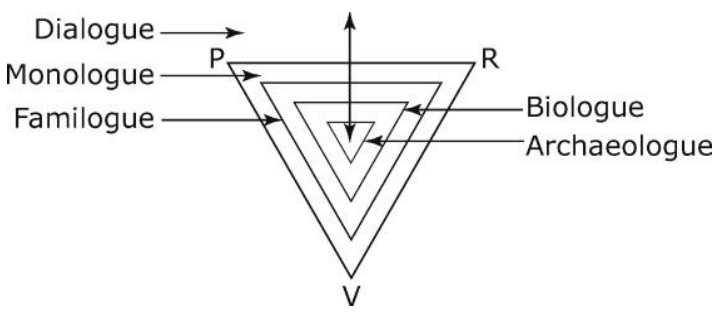

Figure 20: The Darwinian Triangle 3.0

The parent elephants had to empathically feel the Victim position of their offspring, and as Victims felt the alarm that they could lose their future family. The Rescuer role came in to create a protective wall encircling their baby. The Persecutor role came in by aggressively scaring away any predators who could threaten their family. The aggression energy was also needed to search for better food supplies for survival, fight for food, and fight for mates.

The vertical arrow was added to the triangle to represent an in-and-out way of returning to the original harmony.

These were three automatic instincts that all fired off at once and prove necessary for survival of the species, which supports the clinical evidence that three roles of the drama triangle are always present in a game. (Karpman 2014).

\section{Discussion}

The Creative Process

Most of this article has been a checklist showing the way for someone wanting to establish a stable creative international training centre for original thinking and production in the field of psychiatry and psychology. It is a proven system written in detail here that can be followed in steps. There have been other methods that others have used successfully but this is a history lesson of some who made it and some who did not and what can be done.
Eric Berne had a successful system but it was little known outside of his inner circle, and the full method was never collected and assembled in one place until this paper, written from my experience training with him for six years in the late 1960s, and from my long involvement in the ITAA organisation. There is a summary reference to how he ran his weekly seminars in his home in my book (Karpman, 2014). This paper gives examples of the award-winning successes of his followers as well as my own examples of how I used his five rules of creativity, progressing as I needed to create over 20 useful variations of the drama triangle here over the years.

Below I quote from Steve Jobs on connecting the dots, and all the dots that happened in his life to eventually lead him to the point of inventing the iPhone. For me, many triangles (dots) were created over the years from the original one until I found the Darwinian triangle that not only finally proved the three-cornered clinical observation of the compassion triangle but also stimulated discovery of a new three-cornered instinct theory of survival that gets triggered whenever a psychological game begins.

This long process of discovery brings to mind some favourite quotes.

\section{Quotes on creativity}

1. Steve Jobs - Apple's Steve Jobs on the many of his life's adventures leading up to the creation of the iPhone, "Again, you cannot connect the dots looking forward, you can only connect them looking backward so you have to trust that the dots will somehow connect in your future." (Jobs, 2005, paragraph 9).

2. Einstein - one quote by Einstein is applicable to the TV baby elephant story, "Look deep into nature and then you will understand everything better." (Isaacson, 2008).

3. Shakespeare - on the value of continuing the creative process and not knowing what will or will not work but trusting that the results will be there, I quote Shakespeare on trusting a process over time, "If you can look into the seeds of time, and say which grain will grow and which will not, speak then unto me." (Coursen, 1997).

\section{Notes on research}

This paper discusses a research method. We can ask who owns the word 'research'. Does it belong to 'brainstorming research' to produce something new, or is it 'statistical research' to prove what once was new. Or others. Is statistical research useful in the field of psychology? We see papers immediately picked apart for their methodology almost as soon as they are published. Then one day someone else will do research proving it to be wrong or maybe proving the 
opposite. Or a drug company with self-interest could pay for the research. And all the while hardly anyone will ever hear about the research - or believe it because of the variables of the therapists' personalities involved.

Brainstorming ideas can be tried out right away by anyone, and if successful they will keep using them. The drama triangle is an example of brainstorming. It came from doodling 30 pages of diagrams for an hour, writing it up, and people liking it.

Or should the word 'research' be used only for classical research involving thousands of subjects and statistical tabulations with new findings and published in peer-reviewed respected journals that can take years to complete and get published? We know that research for proof is absolutely essential in the physical sciences such as medicine, surgical procedures, pharmacology, nutrition, and others, and is even used in businesses to decide which products they should put their money behind. But can the time and money spent be worth it in the psychotherapy fields with those nagging variables of therapist IQ, ego and personality so difficult to quantify.

If there are these two different valid approaches to researching ideas, brainstorming research and statistical research, then should not the schools of higher learning in the future begin teaching both systems?

This paper recommends that Eric Berne's innovative research system be taught in graduate schools with equal status to other research systems and as a viable and sometimes superior method of acquiring new knowledge.

Stephen B. Karpman, M.D. is a Teaching and Supervising Transactional Analyst and was twice vice president of the ITAA serving on the Board of Trustees for 11 years. Dr. Karpman teaches widely across the United States and abroad. Academically, he is an Assistant Clinical Professor of Psychiatry at UCSF in San Francisco, where he also has his private practice. His articles, many out of print, are available on his free web site at www.KarpmanDramaTriangle.com. All comments to this article are invited by e-mail at egostates@aol.com or on the web site.

\section{References}

Berne, E. (1960 - 1970) 202 seminar personal communications.

Berne, E. (1961) Transactional Analysis in Psychotherapy New York: Grove Press

Berne, E. (1963). The Structure and Dynamics of Organizations and Groups. Montreal: J.B. Lippincott Company.
Berne, E. (1964a). Games People Play: The Psychology of Human Relationships. New York: Grove Press.

Berne, E. (1964b) Trading Stamps. Transactional Analysis Bulletin 3127

Berne, E. (1966). Principles of Group Treatment. New York: Oxford University Press.

Berne, E. (1970). Sex in Human Loving. New York: Simon \& Shuster.

Berne, E. (1972). What do you say after you say hello? The psychology of human destiny. New York: Grove Press.

Coursen, H. (1997). Macbeth. William Shakespeare's Macbeth. Westport, CA: Greenwood Press. Act 1, Scene 3, Line $58-60$

Dusay, J. (1972). Egograms and the Constancy Hypothesis. Transactional Analysis Journal 2(3), 37-41.

Eric Berne Memorial Library (2019)

https://www.ericbernearchives.org/ accessed 14 May 2019

Ernst, F., Jr. (1971) The OK Corral: The Grid for Get-OnWith. Transactional Analysis Journal. 1(4) 33-42

Erskine, R. G. \& Zalcman, M. J. (1979). The racket system: A model for racket analysis. Transactional Analysis Journal, 9. 51-59.

Goulding, R., \& Goulding, M. (1976). Injunctions, decisions, and redecisions. Transactional Analysis Journal, 6 (1), 41 48.

Harris, T.A. (1967). I'm OK - You're OK: A practical guide to transactional analysis. New York: Harper and Row.

Isaacson, W. (2008). Einstein, his life and universe. New York: Simon \& Shuster.

James, M. (1974). Self Reparenting Transactional Analysis Journal 4 (3) 32-39

Jobs, Steve (2005). Text of Steve Jobs' Commencement Address at Stanford University. Stanford University News June 14.

Jorgensen, E.W. and Jorgensen, H.I. (1984) Eric Berne: Master Gamesman. New York: Grove Press.

Kahler, T. with Capers, H. (1974). The Miniscript. Transactional Analysis Journal, 4(1), 26-42.

Karpman, S. (1968). Fairy tales and script drama analysis. Transactional Analysis Bulletin, 7(26). 39-43.

Karpman, S. (1971). Options. Transactional Analysis Journal, 1(1), 79-87.

Karpman, S. (1972) ABC's of hooking the reader's Child. Transactional Analysis Journal, 2(1)

Karpman, S. (1975a). The Bias Box for competing psychotherapies. Transactional Analysis Journal, 5(2). 107116 
Karpman, S. (1975b). The Parent Percolator. Transactional Analysis Journal. 5(4), 365.

Karpman, S. (2006). Lost in translation: Neo-Bernian or Neo-Freudian? Transactional Analysis Journal. 36(4), 284302.

Karpman, S. (2011). The Scientific Model of Eric Berne. ITAA Annual Summer conference in Bilbao.

Karpman, S. (2014). A Game Free Life: The new transactional analysis of intimacy, openness, and happiness: San Francisco. Drama Triangle Publications,

Karpman, S. (2017). The drama triangle and the scientific method of Eric Berne. ITAA annual summer conference in Berlin.

Karpman, S. (2018). The Last Jedi. USATAA TA Gathering. Jamaica

Karpman, S. (2019). Script Drama Analysis II. International Journal of Transactional Analysis Research \& Practice. 10(1) 21-39
Karpman, S., Steiner, C. and Ricciuti, V. (2016). Eric Berne M.D. Selected lectures and seminars. San Francisco 19661970. Eight audio CDs. www.KarpmanDramaTriangle.com

Kupfer, D \& Haimowitz, M (1971) Therapeutic Interventions Part 1 Rubberbands Now. Transactional Analysis Journal 1(1) $10-16$

Levin, P. (1982). The Cycle of Development, Transactional Analysis Journal. 12(2), 129-139.

Mellor. K., \& Schiff, E. (1975a). Discounting. Transactional Analysis Journal (5) 295-30

Mellor. K., \& Schiff, E. (1975b). Redefining. Transactional Analysis Journal (5) 303-311

Schiff, A. W., \& Schiff, J. L. (1971). Passivity. Transactional Analysis Journal, 1(1), 71-78.

Steiner, C. (1966). Script and Counterscript. Transactional Analysis Bulletin 5(18) 133-135

Steiner, C. (2012). Beyond Games and Scripts. New York: Random House 